\title{
The role of industrial estate characteristics in the export decision of manufacturing firms in Indonesia
}

\author{
Meindra Sabri, Nachrowi D. Nachrowi, Widyono Soetjipto \& \\ Maddaremmeng A. Panennungi \\ Department of Economics, Faculty of Economics and Business, Universitas Indonesia, Depok, Indonesia
}

\begin{abstract}
A firm's location determines access to certain economic inputs and trade facilities. The presence of adequate infrastructure and agglomeration economies may boost a firm's export potential. We investigated whether export performance of firms in industrial estates was better than those firms outside industrial estates. We then assessed how industrial estate characteristics determined the export decision of firms in industrial estates. The treatment effect method was used to examine the export performance of firms, and the probit model was developed to explain how industrial estate characteristics (port distance, port capacity, electricity, water, number of tenants and fiscal incentive) affected a firm's export decision. To strengthen the quantitative analysis, we conducted a qualitative analysis through in-depth interviews with the industrial estate top-level managers and related institutions. The results showed that export performance of firms in industrial estates was better than those outside industrial estates. The role of many industrial estate characteristics was significant to the firms' decision to export especially in the Greater Jakarta area. Infrastructure such as electricity and water positively affected the firms' decision to export, but had an opposite direction effect in regions outside Greater Jakarta. Agglomeration economies, which were represented by the number of manufacturing firms, had encouraged firms to export. In addition, government fiscal policy was effective in improving export decision of firms in industrial estates.
\end{abstract}

\section{INTRODUCTION}

Locations have comparative advantages that play a non-negligible role in the potential of individual firms to export. Being located in the same location as other firms can facilitate the firm's capacity to deal with external markets and also to become more successful. Marshall (1890) introduced localization economies where firms get benefit from the availability of specialized input providers, the access to a large pool of similar and specialized labor and the production of new ideas. In addition, Jacobs (1969) argues that firms may benefit from externalities arising in regions with diverse industrial structures or from urbanization economies. While industrial districts were spontaneous localizations of industries through market forces in a delimited area, many governments in the world built some planned counterparts.

The Indonesian government has been trying to boost export of manufacturing industry through the development of industrial estates. An industrial estate is an industrial activity center which is equipped with facilities and infrastructures provided by the industrial estate management. The goal is to locate manufacturing firms in a proper, correct, and environmentally friendly area, so the industry becomes more effective and efficient, hence facilitating future development (the Ministerial Industry Decree No. 35 2010).

We investigated whether the policy was effective to encourage the export performance of firms in industrial estates. Previous studies indicate that special economic areas have positive influence on the export of firms. Schminke and Van Biesebroeck (2013) show that firms in special areas such as Economic and Technological Development Zones (ETDZs) and 
the Science and Technology Industrial Parks (STIPs) in China have a greater total value of exports than firms outside of the two regions. Yi and Wang (2012) state that firms in an economic zone are more likely to export compared to firms outside it.

The problem that arises when comparing the performance of export firms in an industrial estate and those outside of industrial estates is the endogenous nature of firms' location decisions. Being located in an industrial estate might be more advantageous for firms that would have performed better than average anywhere else. This self-selection into industrial estate might result in the upwardly biased estimate of the causal effects on firm's export decision. To solve this problem, we used statistical analysis of cause and effect based on the framework of potential outcomes that refer to Rubin Causal Model (RCM). We need to estimate the potential outcome of treated firms (in the industrial estate) if they had located elsewhere. This counterfactual is inherently unobservable, but we can find the average treatment on the treated (ATT) value base on similar observable covariates under the unconfoundedness and overlap assumptions.

We then assessed how the characteristics of industrial estates determined the export decision of the firms in the industrial estates. From a policy perspective, identifying such determinants is important since industrial estate characteristics influence the costs of exporting through the availability of skills, transport costs, and infrastructure. In line with the theory, firms will choose to export if the expected profit when exporting is higher than the expected profit when operating only on the domestic market. The location in the industrial estates can influence the expectations of firm profits through cost savings from trade and economies of scale. Trade costs are costs in addition to production costs incurred until the goods are received by consumers, and economies of scale are obtained savings through the firm's size, output or scale of operations that cause the cost per unit of output to decline.

This study contributes to the empirical literature in the comparison of the export performance of firms inside and outside of special economic areas in Indonesia. Moreover, using industrial estate characteristics such as distance to the seaport, capacity of the seaport, public infrastructures such as electricity and water, local agglomeration, and incentive fiscal is a new approach to studying the role of location as determinants of firms' decision to export. This approach and the results can be used for future expansion of industrial estates.

This paper is organized as follows. Introduction in Section 1, after that Section 2 reviewed previous studies that discussed determinants of exporting and the role of location characteristics. In Section 3 we outlined our methodology to control firms self-selecting into industrial estates and firm's decision to export. The data is described in Section.4, followed by the estimation results and discussion in Section 5. We closed with conclusions on firm behavior and policy in Section 6.

\section{LITERATURE REVIEW}

Economic zones, namely Industrial Park, Special Economic Zone (SEZ), Industrial Estate (IE), Eco Industrial Park (EIP), Technology Park (TP), and Innovation District (ID), are promoted by many governments around the world to spur economic growth and competitiveness. Firms in the economics zone have advantages through economies of scale and agglomeration, which can influence their decision to export (The World Bank, 2009). Yi and Wang (2012) found that firms in an economic zone are more likely to export compared to firms outside the economic zone. Schminke and Van Biesebroeck (2013) show that export performance of firms in Economic and Technological Development Zones (ETDZs) and the Science and Technology Industrial Parks (STIPs) was better than those of firms outside of both areas in China.

A firm's decision to export is determined by both internal and external factors. The internal factors, firm-specific determinants, are associated with internal economies of scale such as age, size, and productivity (Aitken, Hanson, and Harrison, 1997; Bernard and Jensen, 1999; Greenaway and Kneller, 2007; Roberts and Tybout 1997; Zhao and Zou 2002). The external factors involve external economies of scale in terms of agglomeration (Bernard and Jensen 
2004; Greenaway and Kneller 2008; Koenig, 2009). Agglomeration is the benefit that firms would acquire by being located close to each other in a city or industrial estates as compared to separately located (Glaesere, 2010). In those studies, firm location was merely indicated by a regional dummy variable. The characteristics of the regions were not fully explored as determinants of firms' decision to export.

In the recent approach, Farole and Winkler (2011) and Rodriguez-Pose et al. (2013) found that regional characteristics influence a firms' decision to export, but they are unable to capture the differences among industrial estates that are located within the same regional area. In a region, there can be more than one industrial estate where each has different transportation costs, infrastructures, and numbers of tenants that can affect the costs of exporting. The industrial estate characteristics that influence a firm's decision to export need to be identified because they are related to cost savings from exporting in each industrial estate.

Transportation costs are part of the trading costs that can affect a firm's decision to export (Krugman, et al., 2012). We used the distance from the firm location to the seaport and seaport capacity as the proxies for the transportation costs. The farther the distance, the higher the costs of transportation; therefore, we expected that the distance to the seaport would negatively affect a firm's decision to export. Yi and Wang (2012) found that firms that are located near coastal areas are more likely to export than those located on the mainland. The seaport capacity was thus expected to positively affect a firm's decision to export through a reduction in transportation costs. Abe and Wilson (2011) found that a $10 \%$ increase in port capacity reduces transport costs by up to $3 \%$ in East Asia.

Porter (1998) states that the development of a region or industrial clusters needs government involvement, particularly for providing adequate infrastructure. The state-owned electricity enterprise (PLN) and the state-owned water supply company (PAM) are part of the infrastructure provided by the government. According to the state regulations, the availability of sources of electricity to industrial areas is guaranteed to be uninterrupted. The fact that their prices are relatively cheaper than those of the privately-owned power supply enterprises can reduce the production costs. PAM plays a crucial role in the industrial estates that do not have natural water sources such as rivers. The industrial estates that are not served by PAM distribution have to build their own water treatment plants, and this can significantly increase production costs.

Various types of industries in an industrial estate can form economic urbanization as part of agglomeration. As the number of firms operated in the industrial estate increase, the competition will also increase, which make the firm more productive and tend to export, Long and Zang (2011). Agglomeration can influence firm's decision to export through reducing costs of exporting, Aitken et al. (1997) and raising productivity. Agglomeration can make production costs lower through sharing infrastructure and information and lower transportation and transactions costs through the better relation of suppliers and customers (Malmberg 2009). However, Krugman (1991) stated that in addition to the forces that drive agglomeration (centripetal forces), there is also the forces that against agglomeration (centrifugal forces) and characterized by congestion costs. Congestion costs can raise production costs by the higher price of inputs (land, capital, and labor) and transportation and transactions costs, through longer waiting times (e.g. mobility of intermediate inputs or licenses). These costs may counterbalance the gains from agglomerations, and the net effect can be either positive or negative.

Firms that located in an EPZ or bonded zone which is part of an industrial estate received the fiscal incentive through various taxes. Exemption of import tariff and tax for intermediate input and machinery are given to firms that produce for export market. This fiscal incentive allowed the exploitation of scale economies in production. More firms that have fiscal incentive is expected to influence other firm's decision to export in the industrial estate. This effect is known as export spillover. Previous studies showed positive effects such as Koenig (2009), Farole and Winkler (2011), Rodriguez-Pose et al. (2013), but Bernard and Jensen (2004) didn't find a significant export spillover effect.

Other determinants of export are, but no limited to, export status in the previous year, productivity, amount of labor, source of capital, firm's age, and information availability. Export status in the previous year as a proxy for sunk entry costs has a positive influence on a firm's decision to 
export as Robert and Tybout (1997), Rodriguez et al. (2013), Narjoko and Atje (2007), and Farole and Winkler (2011) have stated. Melitz (2003) shows that only firms with a high productivity can export. Labor is also an important factor of production; more labor implies more output. Sources of capital, especially from abroad bring technological transfer. The higher the foreign share, the higher the export opportunities. Sjöholm and Takii (2008) found that in Indonesia firms that use foreign capital are more likely to export than domestically funded firms. However, the influence of a firm's age on its export decision is still inconclusive. Naudé et al. (2013) state that the starting time to export is an important strategy for firms. Firms often delay this until information is available and requirements such as learning ability, innovation, productivity growth, and access to finance are met. Johanson and Vahlne (1977) argue that making the decision to export is a long process, but adequate transportation facility may shorten that process.

\section{METHODOLOGY}

Treatment effect was used to analyze the export performance of the firms in the industrial estates. Regression adjustment method and inverse probability weighted regression adjustment method, better known as double robust, were used to measure the firms' export intensity and decision to export. These methods could answer the question of whether the firms' performance in the industrial estates was better than those outside of the industrial estates.

To analyze the role of industrial estate characteristics in the firms' decision to export, a combination of quantitative and qualitative analyses was used. For the quantitative analysis, probit regression method was employed and for the qualitative analysis, in-depth interviews with the industrial estate managers and other stakeholders were conducted.

\subsection{Treatment effect}

$\mathrm{y}$ is the outcome variable of performance, and $\mathrm{w}$ is the binary variable of treatment. There are two potential outcomes even though only one can be observed for each firm. If firm $\mathrm{i}$ is in an industrial estate, its potential outcome is $\mathrm{y}_{\mathrm{il}}$, and the potential outcome for the same firm when it is located outside of an industrial estate is $y_{\mathrm{i} 0}$. The average treatment effect (ATE) measures the effect of treatment on a random sample of a particular population, i.e., the effect of an average over the entire population. However, not all firms are willing to enter into an industrial estate, so the measurement of treatment effect needs to be focused on firms that are located in industrial estates. This measurement is called the average treatment effect on the treated (ATT).

ATT is defined as

$$
\tau_{a t t}=\mathrm{E}\left(\left(y_{1}-y_{o}\right) \mid w=1\right)
$$

To get the value $y_{o}$ which is a potential outcome when firms in an industrial estate are located outside, we need two assumptions:

1. Unconfoundedness or ignorability of treatment

$$
\left(y_{1}-y_{0}\right) \perp w \mid x
$$

This first assumption of unconfoundedness or ignorability of treatment, conditioned on a set of covariates x, makes a firm's presence in the industrial estate become random. Covariate variables in $\mathrm{x}$ must be effective in separating the correlation between the potential performance of a firm when it is not located in the industrial estate and the actual value of the firm's performance in the industrial estate.

Weaker assumption of (2) known as independent mean is used, so

$$
\mathrm{E}\left[y_{0} \mid x, w\right]=\mathrm{E}\left[y_{0} \mid x\right]
$$


2. Overlap

When conditioned on a set of control variables $\mathbf{x}$, each unit in the population has the potential to get a treatment

$$
\forall x \in \chi x, 0<P(w=1 \mid x)<1
$$

where $\chi$ is a collection of the covariate. These assumptions guaranteed that for each firm in the sample, there was a counterpart firm outside of industrial estates to be used as a control with the same covariate.

This study used the firms' internal characteristics such as productivity, number of employees, percentage of foreign capital, age, and location as the covariates. The location of the firms was represented by a dummy variable that distinguished whether they were located in Greater Jakarta or outside Greater Jakarta. Export performance was measured by export intensity (total export per output) and the firms' decision to export as a dummy variable which has the value of 1 if they exported and 0 otherwise.

In estimating the average treatment effects, ATT was defined as

$$
\hat{\tau}_{a t t}=\frac{1}{\sum_{i} w_{l}} \sum_{i=1}^{N} w_{i}\left[\hat{m}_{1}\left(x_{i}\right)-\hat{m}_{0}\left(x_{i}\right)\right]
$$

where the functions $\hat{m}_{1}($.$) and \hat{m}_{0}($.$) are the predicted value of the variable performance for$ firms in industrial estates and those outside of industrial estates using the same covariates but can have different coefficients.

\subsection{Firm's decision to export}

The model of firm's decision to export refers to Farole and Winkler's (2011). The decision to export for firm $\mathrm{i}$ at time $\mathrm{t}$ depends on the expected revenue $\mathrm{R}$ and production costs $\mathrm{c}$ and sunk entry costs $\mathrm{S}$ when it began to export.

$$
\mathrm{P}\left(\operatorname{Exp}_{i t}=1\right)=\mathrm{P}\left(R_{i t}>c_{i t}+S\left(1-\operatorname{Exp}_{i t}-1\right)\right)
$$

$E x p=$ export status, where the firm would export if expected profit $\pi_{i t}>0$.

$S=$ sunk entry costs, 0 if the firm exported in period $\mathrm{t}-1$ and 1 otherwise. Sunk entry costs can be either gathering information about the conditions of demand or building the distribution system when entering the export market.

Expected profit $\pi_{i t}^{*}$ was assumed to be influenced by the characteristics of the industrial estates, firms' internal characteristics, and sunk entry costs that could increase or decrease the revenue $\mathrm{R}$ and/or costs $\mathrm{c}$.

Furthermore, the equation (1) was translated into

$$
\mathrm{P}\left(\operatorname{Exp}_{i t}=1\right)=\mathrm{P}\left(\pi_{i t}^{*}=\beta \mathrm{I}_{k t}+\gamma F_{i t}+S\left(1-\operatorname{Exp}_{i t-1}\right)>0\right.
$$

$\pi^{*}{ }_{i t}$ was approximated as a linear combination of $\mathrm{I}_{i t}$ (factor characteristic industrial estate), $F_{k t}$ (internal characteristic factor), and sunk entry costs, which could be observed in period t where subscript $\mathrm{k}$ indicates the industrial estate, $\mathrm{i}$ individual firm and regional $\mathrm{r}$. Then, using the previous year's export status as a proxy for sunk entry costs, the empirical model of firm decision to export could be written as

$$
\begin{aligned}
\operatorname{Exp}_{i r k, t}= & \alpha_{0}+\beta_{1} \text { Inportdistance }_{k t}+\beta_{2} \text { Inportcap }_{k t}+\beta_{3} \text { electricity_pln }_{k t} \\
& +\beta_{4} \text { water_pam }_{k t}+\beta_{5} \text { tenant }_{\mathrm{kt}}+\beta_{6} \text { fiscalincentiveb }_{\mathrm{kt}}+\gamma_{1} \text { Exp }_{i r k, t-1}+\gamma_{2} \text { Inprodt }_{i r k t} \\
& +\gamma_{3} \text { Inemployment }_{i r k t}+\gamma_{4} \text { foreigncapital }_{i r k t}+\gamma_{5} \text { age }_{i r k t}+\gamma_{6}{\text { age } 2_{i r k t}+\varepsilon_{i r k t}}
\end{aligned}
$$


where

- Export: dummy export status, 1 if firm exports and 0 otherwise

- Inportdistance: distance to the sea port in logarithms

- Inportcap: seaport capacity, approached by export volume (thousand tons) in logarithms

- electricity pln: percentage of PLN electricity usage by the total kWh in an industrial estate

- water pam: dummy water source, 1 if PAM water and 0 otherwise

- tenant: number manufacturing firms in logarithms

- fiscalincentive: number of the firms that have bonded area facilities divided by the total number of firms in the industrial estate

- Export t-1: dummy last year export status, 1 if firm exports and 0 otherwise

- Inprodtk: productivity, calculated from the output value divided by the amount of labor in logarithms

- lnemployment: number of workers in logarithms

- foreign capital: percentage of foreign capital

- age: firm's age (years)

- age2: squares of firm's age

\section{DATA}

The database in this study was mainly built from three data sets, (i) industrial estate directory and tenants from the Ministry of Industry, (ii) Large and Medium Industries Survey (IBS) of Statistics Indonesia (BPS) and (iii) export statistics directory from BPS. Information on industrial estate characteristic variables such as distance to the seaport, source of water and number of tenants was sourced from industrial estate directory data, while information on port capacity was sourced from transportation statistics. The percentage of PLN electricity usage by the total $\mathrm{kWh}$ in an industrial estate was sourced from IBS, and the number of the firms that had bonded area facilities in the industrial estate was sourced from the Customs Department. Meanwhile, all of the firms' internal characteristics were sourced from IBS.

There were some data adjustments for data processing. We aggregated the capacity of seaports in Batam as a single value. The capacity of seaport that we used was export volume (thousand tons) from the seaport. We could not find the exact capacity of seaports due to the differences in measurement. The export status of the firm was matched with export statistics if it was empty.

The survey of industrial estate directory conducted by the Ministry of Industry in 2012 covered 59 industrial areas, but after checking the existence of large and medium industries, only 48 industrial estates had data of large and medium industrial firms. The reduction occurred due to (i) the unavailability of tenant data in an industrial estate because it was still under construction and (ii) no matching firms in the IBS data, which can occur when an industrial estate contains many warehouses or offices.

\subsection{Statistics summary}

There were 1583 firms located in the industrial estates at the national level. Based on the concentration of the industrial estates, we divided the national level into two regions the Greater Jakarta area with 24 industrial estates that were located in Jakarta, West Java, and Banten and outside the Greater Jakarta area with 24 industrial estates that were located in 9 provinces (North Sumatera, West Sumatera, Riau, Riau Islands, Lampung, Central Java, East Java, South Sulawesi, and East Kalimantan). Table 1 provides an overview of the variables at the regional level.

The percentage of exporting firms in the Greater Jakarta and outside the Greater Jakarta are about $51 \%$ and $49 \%$ respectively. These indicate that the firm's decision to export in the industrial estates in the Greater Jakarta is higher than outside the Greater Jakarta. 
Table 1. Descriptive statistics of variables.

\begin{tabular}{|c|c|c|c|c|c|c|c|c|c|c|c|c|}
\hline \multirow[b]{3}{*}{ Variables } & \multicolumn{4}{|c|}{ National } & \multicolumn{4}{|c|}{ Greater jakarta } & \multicolumn{4}{|c|}{ Outside greater jakarta } \\
\hline & \multicolumn{4}{|c|}{ (1583 firms) } & \multicolumn{4}{|c|}{ (1117 firms) } & \multicolumn{4}{|c|}{ (466 firms) } \\
\hline & Mean & $\begin{array}{l}\text { Std. } \\
\text { Dev }\end{array}$ & Min & $\operatorname{Max}$ & Mean & $\begin{array}{l}\text { Std. } \\
\text { Dev }\end{array}$ & Min & $\operatorname{Max}$ & Mean & $\begin{array}{l}\text { Std. } \\
\text { Dev }\end{array}$ & Min I & $\operatorname{Max}$ \\
\hline Export & 0.51 & 0.5 & 0 & 1 & 0.51 & 0.5 & 0 & 1 & 0.49 & 0.5 & 0 & 1 \\
\hline ort distance & 3.32 & 0.87 & & 5.2 & 3.57 & 0.73 & & 5.2 & 2.73 & 0.89 & 0 & 4.09 \\
\hline Port c & 8.99 & 0.86 & 5.4 & 10.42 & 9.3 & 0.45 & 7.06 & 9.39 & 8.24 & 1.1 & 5.48 & 10.42 \\
\hline PLN & 0.67 & 0.34 & & 1 & 0.63 & 0.36 & & 1 & 0.78 & 0.29 & 0 & 1 \\
\hline Water PAM & 0.34 & 0.47 & & 1 & 0.19 & 0.39 & & 1 & 0.7 & 0.46 & 0 & 1 \\
\hline Tenant & 4.18 & 1.07 & & 5.68 & 4.45 & 0.99 & 0 & 5.68 & 3.54 & 0.99 & 0 & 4.8 \\
\hline Fiscal incentive & 0.17 & 0.18 & & 1 & 0.2 & 0.2 & 0 & 1 & 0.2 & 0.2 & 0 & 1 \\
\hline Export last year & 0.49 & 0.5 & 0 & 1 & 0.5 & 0.5 & 0 & 1 & 0.5 & 0.5 & 0 & 1 \\
\hline Productivity & 12.91 & 1.32 & 7.85 & 18.15 & 13 & 1.3 & 7.8 & 18.1 & 12.7 & 1.3 & 9.2 & 17.8 \\
\hline Employment & 4.84 & 1.35 & & 10.17 & 4.9 & 1.4 & 3 & 9.1 & 4.8 & 1.3 & 3 & 10.2 \\
\hline Foreign capital & 41.65 & 47.08 & & 100 & 45.7 & 47.1 & 0 & 100 & 31.8 & 45.5 & 0 & 100 \\
\hline Age & 15.83 & 39.17 & & 100 & 15 & 7.5 & 1 & 67 & 17.8 & 12.1 & 1 & 100 \\
\hline Age2 & 334.51 & 1536.84 & & 10000 & 280.2 & 331.7 & 1 & 4489 & 464.6 & 832.1 & 1 & 10000 \\
\hline
\end{tabular}

The port distance to the industrial estate in the Greater Jakarta area on average is farther away from the seaport than outside the Greater Jakarta area. It has higher average that caused by many industrial estates located in Bekasi, Karawang, and Purwakarta. The average of seaport capacity is higher in the Greater Jakarta than the outside the Greater Jakarta area. The Greater Jakarta region has fewer ports, but has a relatively large capacity greater than outside the Greater Jakarta.

For infrastructure, the average use of PLN power in the industrial estates in the Greater Jakarta area is $63 \%$, lower than the outside of the Greater Jakarta that reached $78 \%$. It shows the dependence of the industrial estates on PLN power outside the Greater Jakarta is higher. The PAM water is only used by $19 \%$ of firms in the industrial estates in the Greater Jakarta area, much lower than outside the Greater Jakarta where $75 \%$ of firms. The average number of tenants in the Greater Jakarta is higher than outside the Greater Jakarta. Fiscal incentive on average in the industrial estate is higher than outside the Greater Jakarta. It means there are more firms accept fiscal incentive.

The export status in the previous year shows that in both regions $50 \%$ of firms were exporting. The average productivity in the Greater Jakarta is higher than outside the Greater Jakarta. The number of labor is relatively indifferent between the two regions. The average of foreign capital in the Greater Jakarta is higher than outside the Greater Jakarta area, It shows more firms with higher foreign capital are located in the Greater Jakarta. Firm's age in the Greater Jakarta tends to be younger than outside the Greater Jakarta.

\section{RESULTS}

\subsection{Export performance of firm in the industrial estate}

The firms' export performance was measured using two variables, export intensity and export decision. By using regression adjustment and inverse-probability-weighted regression adjustment, we obtained the value of Average Treatment Effects on the Treated (ATT) as follows:

The firms located in an industrial estate had a higher level of export intensity and export decision than the control firms. Both regression methods gave similar results in that the difference was positive and highly significant at the $1 \%$ level as shown in Table 2 . Using regression adjustment, the export intensity of firms in the industrial estates was $3.5 \%$ higher than 
Table 2. Export performance.

\begin{tabular}{lll}
\hline ATT & Regression adjustment & $\begin{array}{l}\text { Inverse-probability-weighted } \\
\text { regression adjustment }\end{array}$ \\
\hline Export intensity & $0.0353^{* *}$ & $0.0493^{* * *}$ \\
Export decision & $0.355^{* * *}$ & $0.355^{* * *}$ \\
\hline
\end{tabular}

the average export intensity of firms outside the industrial estates and $4.9 \%$ higher using inverse-probability-weighted regression adjustment. Firms' decision to export in the industrial estates had 0.36 propensity score higher than the control firms outside the industrial estates for both methods. We can say that export performance of firms in the industrial estates was better than that of firms outside of the industrial estates.

\subsection{The role of industrial estate characteristics on firm's export decision}

At the national level, there were 1583 firms. Greater Jakarta had 1117 firms or $71 \%$ of the total observations, while the regions outside Greater Jakarta had 466 firms or $29 \%$ of total observations. By using probit models (see Table 3), the estimation of various sets of data was robust to heteroscedasticity. The standard error was clustered by the seaports so that errors could be correlated between the firms that accessed the same seaports. The regressions showed that the model used was good enough, where the Hosmer-Lemeshow test showed that the goodness-of-fit statistic $\chi 2$ value was not significant. Furthermore, the significance of the regression coefficients for each variable was based on $10 \%, 5 \%$, and $1 \%$ level.

The distance to the seaport has a significant positive effect in the Greater Jakarta means that a greater distance of an industrial estate from sea port will increase firm's decision to export, but it was insignificant for outside the Greater Jakarta. These results contradicted to the hypothesis that stated the greater the distance will increase transportation costs and lower the firm's export decision. The possible reason is the economic benefit from production costs outweighed the effect of increasing transportation costs. From the interview, all industrial estates have highway access to the seaports. The toll road is relatively smooth so that the more distance is unnecessarily increase the transportation costs in the Greater Jakarta area.

Seaport capacity has no significant effect on the firm's export decision in the industrial estate in the Greater Jakarta area. There are only two seaports in the Greater Jakarta, and most of the firms access the same port (Tanjung Priok). For the outside the Greater Jakarta, seaport capacity has a significant negative effect on the firm's exports decision. This is caused by non-optimal exporting of manufacturing firms in the outside Greater Jakarta. Port with larger capacity is accessed by fewer exporting firms. A Large share of the port capacity used by economics sectors that were based on natural resources such as agriculture and mining. We didn't find the effect of costs saving as in Abe and Wilson (2011) who found that increasing the port's capacity by $10 \%$ will reduce transport costs of up to $3 \%$ in East Asia.

PLN power source has a positive effect for the greater Jakarta area. A higher percentage of the PLN electricity in the industrial estate will improve firm's decision to export. The existence of alternative power sources that has excellent reliability made PLN improve their quality of services by providing premium power. The quality is guaranteed from shutting down or flicker. Based on the experiences of respondents who used the premium PLN power, flicker might turn off the large and sensitive production machine. Production costs will increase because of the large machines need time to be able to work normally after a flash happens.

In the outside Greater Jakarta, PLN electricity has a negative effect which means that the greater portion of PLN power in an industrial estate will reduce firm decision to export. This result was influenced by the industrial estate that has a high percentage PLN power usage is mostly occupied by firms that do not export. Conversely, the industrial estate that has its power source is mostly occupied by firms that export. This result indicates that PLN has not been able to meet the capacity or quality of the power required by exporting firms in the industrial estate. Industrial estates have to build its power source according to the needs of its tenants. 
Table 3. Results of regression at regional level.

\begin{tabular}{llll}
\hline Variable & National & Greater jakarta & $\begin{array}{l}\text { Outside greater } \\
\text { jakarta }\end{array}$ \\
\hline Port distance & 0.104 & $0.174^{* * *}$ & 0.144 \\
Port capacity & 0.0301 & 0.0493 & $-0.198^{* *}$ \\
PLN Electricity & -0.113 & $0.0348^{* * *}$ & $-0.879^{* * *}$ \\
PAM Water & $0.183^{*}$ & $0.265^{* * *}$ & $-0.365^{* * *}$ \\
Tenants & -0.0224 & $0.0508^{* * *}$ & 0.204 \\
Fiscal incentive & $1.045^{* *}$ & $1.644^{* * *}$ & -0.217 \\
Export last year & $3.194^{* * *}$ & $3.223^{* * *}$ & $3.551^{* * *}$ \\
Productivity & $0.0727^{* *}$ & 0.048 & $0.222^{*}$ \\
Employment & 0.0531 & -0.00793 & $0.282^{* * *}$ \\
Foreign capital & $0.00329^{* * *}$ & $0.00201^{* * *}$ & $0.0121^{* *}$ \\
Age & $0.0374^{* * *}$ & $0.0346^{* * *}$ & 0.00962 \\
Age2 & $-0.000721^{* * *}$ & $-0.000240^{* * *}$ & $-0.000669^{*}$ \\
Cons & $-3.843^{* * *}$ & $-4.228^{* * *}$ & $-4.693^{* *}$ \\
$\mathrm{~N}$ & 1583 & 1117 & 466 \\
\hline
\end{tabular}

$* \mathrm{p}<0.1, * * \mathrm{p}<0.05, * * *<0.01$.

PAM water has a positive significant effect on firm's decision to export in the industrial estate in the Greater Jakarta area, which means that firms in the industrial estate that use PAM water are more likely to export than firms in the industrial estate that does not use PAM water. PAM limitations regarding water supply for the industrial estate causing many industrial estates treat their water needs by utilizing river water or ground water, especially in the area of Bekasi, Karawang, and Purwakarta. Water treatment independently by operators of industrial estates may increase production costs due to the price of water is more expensive. On the other hand, PAM water has a significant negative effect on outside the Greater Jakarta area where more exporting firms located in the industrial estate that has an independent water source. Conversely, in the industrial estate that used PAM water, fewer firms are exporting. Like the PLN power, there is a tendency that industrial estate whose many tenants are exporting build water installations independently.

The number of tenants has a positive significant effect on decision-export company in the industrial estate in the Greater Jakarta area. More tenants can improve interaction between firms so that the positive effects of agglomeration becomes more prominent as described Marshall (1890) and Jacob (1969). From the interviews, we obtained information that the industrial estate that has many tenants usually have a major firm or industry (anchor). For example, automotive firms get components from supplier firms that located in the same industrial estate. Likewise, fiscal incentives have a positive influence on firm's export decisions. More firms that received fiscal facilities (bonded zone) in the industrial estate made firm's export decision increase. This result shows the positive effect of the export spillover through the existence of the bonded zone in the industrial estate. Both of variables, the number of tenants in an industrial estate and the number of firms in the bonded zone showed that economic agglomeration in the industrial estate significantly influences the firm's decision to exports.

Exports last year is a proxy of sunk entry cost has a significant positive effect on firm's decisions to export in the Greater Jakarta and outside the Greater Jakarta. Firms that export in the previous year tends to re-export. The tendency to maintain exports is greater in firms that located outside the Greater Jakarta area. The first time export of firm that located outside the Greater Jakarta needs greater sunk entry cost than the Greater Jakarta area. The results previous export role, support the empirical study of firm's decision to export such as Rodriguez et al. (2013), and Farole and Winkler (2011).

Productivity has no significant impact on exporting firms in the Greater Jakarta area. This result showed that firms with low productivity also export. From the interview, we get 
information that in the Greater Jakarta area, many firms were not only supplying components to a larger company, but also export. For outside the Greater Jakarta area, productivity has a significant positive effect following Melitz (2003) which states that only high-productivity firms could export. The number of workers is insignificant to firm's decision to export in the greater Jakarta area. It showed that not only the big firms do export but also mediumsized firms. Different result occurred at the outside Greater Jakarta where big firms have more tendency to export than middle size firms.

Foreign capital has a significantly positive influence in both the greater Jakarta area and outside Greater Jakarta areas. A high portion of foreign capital encouraged the firm to export in the industrial estate. These results support Sjöholm and Takii (2008) who found that foreign capital firms are more likely to export than domestically funded firms in Indonesia. The main reason of why foreign capital might encourage export is global production network. Multinational companies established factories in several countries that have different comparative advantages as Athukorala (2010), Jones and Kierzkowski (2001). From interviews, we obtained information that the ownerships of almost all industrial estates in the greater Jakarta area are a joint venture company, in which most of the foreign ownership came from Japan and South Korea. The presence of this foreign ownership can foster the confidence of investors to invest in Indonesia and located in the industrial estate which they managed.

Firm's age has a significant positive effect in the Greater Jakarta and outside Greater Jakarta area. Older firms have a greater probability to export. This result is consistent with Jan and Vahlne (1977) who shows that export is a gradual development process. But when we use squared of age, the coefficient is negative. It means that firms age is positively increasing the probability to export, but the marginal increase is decreasing.

\section{CONCLUSION}

Exporting firms performed better when located inside rather than outside the industrial estates. At the regional level, industrial estate characteristics gave different results across the regions. Almost all of the industrial estate characteristics had a significant effect on export in the Greater Jakarta area, which is consistent with the hypothesis. Local agglomeration had a significantly positive effect, and the fiscal policy shows that the number of firms in bonded zone had a positive influence on firms in the industrial estates to export.

The policy of development of industrial estates is appropriate and should be continued to encourage the export of the manufacturing industry. Different roles of the industrial estate characteristics across regional areas add to the evidence that the Greater Jakarta area is still an excellent choice of location. The industrial estates in Greater Jakarta are typically managed by private owners in collaboration with foreign parties which have a significant role in the development of industrial estates in Indonesia.

\section{REFERENCES}

Abe, Kazutomo and John S. Wilson. 2011. "Investing in Port Infrastructure to Lower Trade Costs in East Asia." Journal of East Asian Economic Integration 15 (2): 3-32. https://ssrn.com/abstract $=2318301$.

Aitken, Brian, Gordon Hanson, and Ann E. Harrison. 1997. "Spillovers, Foreign Investment, and Export Behavior." Journal of International Economics 43: 103-32. doi:10.1016/S0022-1996(96)01464-X.

Athukorala, Prema-chandra. (2010). Production Networks and Trade Patterns in East Asia: Regionalization or Globalization? The ADB Working Paper Series on Regional Economic Integration. No. 56 August 2010.

Bernard, Andrew B, and J Bradford Jensen. 2004. "Why Some Firms Export." The Review of Economics and Statistics 86 (2): 561-69. doi:10.1162/003465304323031111.

Farole, Thomas, and Deborah Winkler. 2011. "Firm Location and the Determinants of Exporting in Developing Countries." The World Bank. Policy Research Working Paper 5780: 67-102. http://dx.doi. org/10.1596/9780821398937_CH03. 
Glaeser, Edward L. (2010). Agglomeration Economics. The University of Chicago Press. ISBN: 0-226-29789-6.

Greenaway, David, and Richard Kneller. 2007. "Firm Heterogeneity, Exporting and Foreign Direct Investment." The Economic Journal 117 (517): F134-61. doi:10.1111/j.1468-0297.2007.02018.x.

Greenaway, D. and R. Kneller. 2008 "Exporting, Productivity and Agglomeration." European Economic Review 52 (5): 919-39. doi:10.1016/j.euroecorev.2007.07.001.

Jacobs, Jane. 1969. The Economics of Cities. Vintage, New York.

Johanson, Jan, and Jan-Erik Vahlne. 1977. "The Internationalization Process of the Firm-A Model of Knowledge Development and Increasing Foreign Market Commitments." Journal of International Business Studies 8 (1): 23-32. doi:10.1057/palgrave.jibs.8490676.

Jones, R.W. Kierzkowski, H. (2001). Globalization and the Consequences of International Fragmentation. In R. Dornbusch, G. Calvo, and M. Obstfeld, eds. Money, Factor Mobility and Trade: The Festschrift in Honor of Robert A. Mundell. Cambridge, Mass: MIT Press. pp. 365-381.

Koenig, Pamina. 2009. "Agglomeration and the Export Decisions of French Firms." Journal of Urban Economics 66 (3): 186-95. doi:10.1016/j.jue.2009.07.002.

Krugman, Paul R., Maurice Obstfeld, and Marc J. Melitz. 2012. International Economics : Theory and Policy. 9th Ed. New York: Pearson Publishing Ltd.

Krugman, Paul. 1991. "Increasing Returns and Economic Geography." Journal of Political Economy 99 (31): 483-99. doi:10.1086/261763.

Long, Cheryl, and Xiaobo Zhang. 2011. "Cluster-Based Industrialization in China: Financing and Performance." Journal of International Economics 84 (1): 112-23. doi:10.1016/j.jinteco.2011.03.002.

Malmberg, Anders. 2009. "Agglomeration.” In International Encyclopedia Of Human Geography, edited by Rob Kitchin and Nigel Thrift, 48-53. USA: Elsevier Ltd.

Marshall, Alfred. 1890. Principles of Economics. Available from http://eet.pixel-online.org/files/etranslation/original/Marshall,\%20Principles\%20of\%20Economics.pdf Accessed on August 17, 2016.

Melitz, Marc J. 2003. "The Impact of Trade on Intra-Industry Reallocations and Aggregate-Industry Productivity." Econometrica 71 (6): 1695-1725. doi:10.1111/1468-0262.00467.

Narjoko, Dionisius A., and Raymond Atje. 2007. "Promoting Export: Some Lessons from Indonesian Manufacturing” Asia-Pacific Research and Training Network on Trade Working Paper Series 32: $1-47$.

Naudé, Wim, Thomas Gries, and Bilkic Natasa. 2013. Firm-Level Heterogeneity and the Decision to Export: A Real Option Approach. IZA Discussion Paper 7346: 1-29.

Porter, Michael E. 1998. "Clusters and the New Economics of Competition Harvard Business Review." Harvard Business Review 76 (6): 77-90. doi:10.1042/BJ20111451.

Roberts, Mark J., and James R. Tybout. 1997. "The Decision to Export in Colombia: An Empirical Model of Entry with Sunk Costs." American Economic Review 87 (4): 545-64. doi:10.2307/2951363.

Rodrıguez-Pose, Andres, Vassilis Tselios, Deborah Winkler, and Thomas Farole. 2013. "Geography and the Determinants of Firm Exports in Indonesia." World Development 44: 225-240. http://dx.doi. org/10.1016/j.worlddev.2012.12.002.

Schminke, Annette, and Johannes Van Biesebroeck. 2013. "Using Export Market Performance to Evaluate Regional Preferential Policies in China." Review of World Economics 149 (2): 343-67. doi:10.1007/ s10290-012-0145-y.

Sjöholm, Fredrik, and Sadayuki Takii. 2008. "Foreign Networks and Exports: Results from Indonesian Panel Data." Developing Economies 46 (4): 428-46. doi:10.1111/j.1746-1049.2008.00072.x.

The World Bank.(2009). World Development Report. Reshaping Economic Geography.

Yi, Jingtao, and Chengqi Wang. 2012. "The Decision to Export: Firm Heterogeneity, Sunk Costs, and Spatial Concentration." International Business Review 21 (5): 766-81. doi:10.1016/j.ibusrev.2011.09.001.

Zhao, Hongxin, and Shaoming Zou. 2002. "The Impact of Industry Concentration and Firm Location on Export Propensity and Intensity: An Empirical Analysis of Chinese Manufacturing Firms." Journal of International Marketing 10 (1): 52-71. doi:10.1509/jimk.10.1.52.19527. 